\title{
Ketentuan Hukum Mengenai Mangkir dalam Omnibus Law
}

\author{
Febri Jaya ${ }^{1}$, Alvin Lauw ${ }^{2}$ \\ ${ }^{1}$ Fakultas Hukum, Universitas Internasional Batam \\ ${ }^{2}$ Fakultas Hukum, Universitas Internasional Batam \\ Correspondence email : febri.jaya@uib.ac dan alvinlauw2889@gmail.com
}

\begin{abstract}
Abstrak. Banyaknya regulasi yang ada di Indonesia sering kali memberikan dampak berkurangnya keefektifan pelaksanaan aturan perundang-undangan yang dikarenakan adanya saling tumpang tindih antar aturan. Dengan diberlakukannya UndangUndang Nomor 11 Tahun 2020 Tentang Cipta Kerja, maka banyak aturan ketenagakerjaan yang diubah salah satunya terkait dengan Perjanjian Kerja Waktu Tertentu. Oleh karena itu, penelitian ini bertujuan untuk melakukan kajian terhadap perubahan ketentuan dalam Perjanjian Kerja Waktu Tertentu tentunya mempengaruhi hak dan kewajiban antara pekerja dan pengusaha, perubahan ini harus dapat dipahami oleh pekerja maupun pengusaha sehingga undang-undang ini dapat berlaku secara efektif. Melalui penelitian hukum normatif maka dapat diketahui bahwa ada beberapa hal yang kemudian perlu dibahas terkait dengan berlakunya dengan Undang-Undang Nomor 11 Tahun 2020 Tentang Cipta Kerja. Sebagai hasil pembahasan, penelitian ini menguraikan mengenai mangkir dan hak-hak pengusaha jika pekerja mengakhiri Perjanjian Kerja Waktu Tertentu sebelum waktu perjanjian berakhir.
\end{abstract}

Kata Kunci: Cipta Kerja, Mangkir, Perjanjian Kerja Waktu Tertentu

Abstract. The number of existing regulations in Indonesia often has the effect of reducing the effectiveness of implementing laws and regulations due to the overlap between regulations. With the enactment of Act Number 11 of 2020 on Job Creation, many labor regulation have been changed, one of which is related to a specific time work agreement. Therefore, this study aims to conduct a study on change to the provision in the employment agreement for a certain period of time, which certainly affects the rights and obligation between worker and employment, this change must be understood by both worker and employment. Through normative legal research, it can be seen that there are a number of things that need to be discussed in relation to the enactment of Act Number 11 of 2020 on Job Creation. As a result of discussion, this study describes absenteeism and the rights of employment if the worker terminates the employment agreement for a certain period of time before the end of the agreement.

Keywords: Job Creation, Absenteeism, Fixed Time Work Agreement

\section{PENDAHULUAN}

Kehadiran hukum ketenagakerjaan secara keseluruhan adalah untuk memberikan perlindungan hukum bagi pekerja dan pengusaha. Satu dan lain hal, pembentukan hukum ketenagakerjaan bertujuan untuk menjaga harmonisasi antar pekerja dan pengusaha agar terjalin suatu hubungan yang baik untuk menciptakan suasana perekonomian yang baik pula.

Keseimbangan pemberian perlindungan hukum bagi pekerja dan pengusaha tentu akan berdampak pada proses realisasi kegiatan usaha yang memberikan kesempatan berimbang bagi pekerja dan pengusaha untuk melakukan segala tindakan dan/atau perbuatan hukum. Bilamana pengusaha melakukan perbuatan dan/atau tindakan-tindakan yang berlawanan dengan hukum, maka pekerja memiliki hak untuk membantah (atau melawan) melalui mekanisme hukum yang ada.

Berlaku juga sebaliknya, bila pekerja yang melakukan pelanggaran atas hukum ketenagakerjaan, maka pengusaha secara teoritis memiliki hak pula untuk mempersoalkan pelanggaran tersebut sesuai dengan mekanisme hukum yang berlaku. Dalam hubungan industrial akan selalu terjadi perbedaan pendapat atau serikat pekerja/serikat buruh. Padahal hubungan antara pengusaha dengan pekerja/buruh atau serikat pekerja merupakan hubungan yang didasari oleh kesepakatan para pihak mengikatkan hubungan kerja. ${ }^{1}$

Salah satu hal yang menurut hemat Penulis menarik untuk dibahas ikhwal perlindungan pekerja dan pengusaha adalah dalam hal pembuatan perjanjian kerja waktu tertentu. Secara sekilas tentu pembuatan perjanjian tersebut merupakan hal yang mudah dan tidak memiliki persoalan yang rumit. Sesuai dengan hukum yang berlaku, siapapun pihak yang melakukan pengakhiran perjanjian sebelum jangka waktu perjanjian berakhir, maka pihak tersebut memiliki kewajiban untuk membayar ganti kerugian kepada pihak satunya tersebut.

Namun penerapan hukum tidaklah mudah bilamana salah satu pihak sejak awal telah memiliki itikad yang tidak baik dalam melaksanakan prestasi dalam perjanjian yang telah disepakati bersama. Sebagai salah satu contoh, pekerja yang secara sengaja maupun tidak melakukan tindakan berupa alpa (tidak hadir bekerja) selama 5 hari berturut-turut

${ }^{1}$ Velis Alicia Pui, “Analisis Yuridis Penyelesaian Sengketa Pemutusan Hubungan Kerja Terhadap Tenaga Kerja Asing Melalui Mediasi (Studi Penelitian di Dinas Tenaga Kerja Kota Batam)”, Jurnal Wajah Hukum, Volume 4 No 2, 2020 , hlm. 445. 
tanpa alasan yang jelas. Sesuai dengan ketentuan hukum ketenagakerjaan yang berlaku, tentu tindakan pekerja tersebut merupakan kualifikasi tindakan mangkir sehingga pekerja yang bersangkutan dianggap mengundurkan diri.

Pertanyaan lanjutan atas tindakan mangkir tersebut adalah apakah segala kewajiban pekerja telah terpenuhi dengan baik? Tentu dalam keadaan ini, sesuai dengan kebiasaan dalam hukum perusahaan yang ada, seorang pekerja yang mengundurkan diri lazimnya melakukan berbagai tindakan sebagai konsekunsi logis atas berakhirnya hubungan kerjanya dengan pengusaha, seperti seraha terima pekerjaan sampai dengan serah terima segala dokumen terkait dengan pekerjaan.

Dalam hal pekerja mangkir terdapat hak-hak pengusaha yang tentu harus dilindungi secara hukum. Agar pengusaha tidak mengalami tindakan-tindakan hukum yang merugikan, menurut hemat penulis, perlu ada kajian secara komprehensif terhadap perlindungan hak-hak pengusaha saat pekerja mangkir terutama terhadap pekerjapekerja yang masih terikat PKWT. Isu ini merupakan salah satu yang layak untuk dibahas selain isu-isu lain yang pernah menjadi pembahasan saat pembahasan Rancangan Undang-Undang Cipta Kerja. ${ }^{2}$

Berdasarkan latar belakang di atas, peneliti ingin meneliti hal-hal sebagai berikut:

1. Bagaimana keadaan pekerja dapat dikualifikasi mangkir sesuai dengan ketentuan hukum yang berlaku dikaitkan dengan Undang-Undang Cipta Kerja serta aturan turunannya?

2. Bagaimana hak pengusaha saat pekerja dengan Perjanjian Kerja Waktu Tertentu mengakhiri perjanjian sebelum jangka waktu perjanjian kerja berakhir?

\section{METODE}

Metode penelitian merupakan bagian dalam suatu penelitian yang menjelaskan jenis penelitian yang digunakan dalam melakukan pendekatan dalam penelitian ilmiah. Selanjutnya, penelitian merupakan: "suatu sarana pokok dalam pengembangan ilmu pengetahuan maupun teknologi yang disimpulkan dengan tujuan mengungkapkan kebenaran secara sistematis, metodologis, dan konsisten. Sehingga melalui proses penelitian serta analisa terhadap data ada". ${ }^{3}$

Fungsi penelitian adalah untuk "mendapatkan kebenaran dari segi epistemologis dengan pengertian kebenaran harus dilihat dari epistemologi". ${ }^{4}$ Adapun penulisan artikel ini menggunakan jenis penelitian hukum secara normatif. Sesuai dengan literasi hukum secara kepustakaan ${ }^{5}$ merupakan penelitian yang dilakukan dengan mengkaji peraturan perundang-undangan yang berlaku dan bahan-bahan pustaka lainnya yang lazimnya dinamakan data sekunder, untuk diterapkan terhadap suatu permasalahan hukum tertentu. ${ }^{6}$

Ilmu hukum merupakan satu disiplin keilmuan yang memiliki karakter yang khas yang dengan sifat normatif. ${ }^{7}$ Fokus perhatian ilmu hukum normatif ialah mengubah keadaan serta menawarkan penyelesaian terhadap permasalahan kemasyarakatan yang konkret maupun potensial. ${ }^{8}$ Dalam pembentukan hukum, proses konkretisasi dan individualisasi peraturan hukum yang bersifat umum dihubungkan dengan peristiwa konkret. ${ }^{9}$ Usia suatu peraturan perundang-undangan seringkali menyebabkan kekosongan dalam pengaturan subtansi hukum. Oleh karena itu, dalam aspek penegakan hukum terhadap peraturan perundang-undangan tersebut tentu tetap harus memperhatikan kaedahkaedah hukum yang telah ada. ${ }^{10}$

\section{HASIL DAN PEMBAHASAN}

\section{Kualifikasi karyawan Mangkir Berdasarkan Undang-Undang Cipta Kerja}

Sebelum membahas lebih lanjut aturan perundang-undangan yang mengatur tentang kualifikasi karyawan yang mangkir di perusahaan maka perlu terlebih dahulu dibahas apa yang dimaksud dengan mangkir. Berdasarkan Kamus Besar Bahasa Indonesia, mangkir adalah tidak datang (ke sekolah, ke tempat kerja, dan sebagainya); absen. Dari pengertian tersebut diketahui bahwa mangkir adalah keadaan dimana seseorang tidak datang ke tempat kerja atau yang biasanya disebut dengan absen. berbunyi:

Di Undang-Undang Cipta Kerja sendiri aturan mengenai pekerja yang mangkir diatur dalam Pasal 154A yang

${ }^{2}$ Febri Jaya, "Perlindungan Hak-Hak Pekerja Perempuan Pasca Rev
, Jurnal Kertha Semaya, Volume 8, No. 12, 2020, hlm. 1887-1888.

3 Soekanto, Soerjono dan Sri Mamudji. Penelitian Hukum Normatif Suatu Tinjauan Singkat, (Jakarta, RajaGrafindo Persada, 2003), hlm. 1.

${ }^{4}$ Marzuki, Peter Mahmud. Penelitian Hukum, (Jakarta, Kencana, 2014), hlm. 20.

${ }^{5}$ Soekanto, Soerjono dan Sri Mamudji. Op. Cit., hlm. 23-24.

${ }^{6}$ Ibid. hlm. 14.

${ }^{7}$ Ibrahim, Johnny. Teori dan Metode Penelitian Hukum Normatif, (Malang, Bayumedia Publishing, 2003), hlm. 12.

${ }^{8}$ Ibid. hlm. 293.

${ }^{9}$ Ibid.

${ }^{10}$ Ibid. hlm. 158-159. 
“(1) hubungan kerja dapat terjadi karena: j. pekerja/buruh mangkir selama 5 (lima) hari kerja atau lebih berturutturut tanpa keterangan secara tertulis yang dilengkapi dengan bukti yang sah dan telah dipanggil oleh pengusaha 2 (dua) kali secara patut dan tertulis;”

Dalam aturan tersebut diketahui bahwa untuk dikategorikan mangkir adalah:

1. Tidak masuk bekerja selama 5 hari kerja atau lebih

Setiap pekerja diwajibkan untuk menjalankan pekerjaannya di lokasi kerja yang telah ditentukan oleh pengusaha. Tidak hadirnya pekerja tentu mengganggu proses operasional perusahaan yang mengakibatkan kerugian perusahaan terutama jika tidak ada informasi terkait alasan pekerja. Dengan diberikannya jangka waktu maka diberikan perlindungan kepada pengusaha untuk mengambil tindakan lainnya yang tidak merugikan perusahaan seperti mencari pekerja baru untuk menggantikan posisi pekerja yang tidak masuk.

2. Tidak ada keterangan yang tertulis dengan bukti yang sah

Dalam Undang-undang sendiri diatur bahwa tidak semua jenis mangkir dapat dikategorikan sebagai tindakan menuju putusnya hubungan kerja sebab di dalam Undang-Undang sendiri diatur alasan-alasan mangkir yang dilindungi dalam undang-undang seperti yang ada di dalam Pasal 153 (1) Undang-Undang Cipta Kerja:

"Pengusaha dilarang melakukan pemutusan hubungan kerja kepada pekerja/buruh dengan alasan:

a. berhalangan masuk kerja karena sakit menurut keterangan dokter selama waktu tidak melampaui 12 (dua belas) bulan secara terus-menerus;

b. berhalangan menjalankan pekerjaannya karena memenuhi kewajiban terhadap negara sesuai dengan ketentuan peraturan perundangundangan;

c. menjalankan ibadah yang diperintahkan agamanya;

d. menikah;

e. hamil, melahirkan, gugur kandungan, atau menyusui bayinya;

f. mempunyai pertalian darah dan/atau ikatan perkawinan dengan pekerja/buruh lainnya di dalam satu perusahaan;

g. mendirikan, menjadi anggota dan/atau pengururs serikat pekerjalserikat buruh, pekerja/buruh melakukan kegiatan serikat pekerja/serikat buruh di luar jam kerja, atau di dalam jam kerja atas kesepakatan pengusaha, atau berdasarkan ketentuan yang diatur dalam perjanjian kerja, peraturan perusahaan, atau perjanjian kerja bersama;

h. mengadukan pengusaha kepada pihak yang berwajib mengenai perbuatan pengusaha yang melakukan tindak pidana kejahatan;

i. berbeda paham, agama, aliran politik, suku, warna kulit, golongan, jenis kelamin, kondisi fisik, atau status perkawinan; dan

j. dalam keadaan cacat tetap, sakit akibat kecelakaan kerja, atau sakit karena hubungan kerja yang menurut surat keterangan dokter yang jangka waktu penyembuhannya belum dapat dipastikan."

Alasan tersebut tidak dapat dijadikan dasar putusnya hubungan kerja sekalipun karyawan bisa saja tidak bekerja sampai 5 (lima) hari atau bahkan lebih. Oleh sebab itu maka selain alasan-alasan diatas maka jika pekerja tidak masuk bekerja dapat dianggap sebagai sebuah tindakan mangkir yang dapat berakibat putusnya hubungan kerja.

3. Telah dipanggil oleh pengusaha 2 (dua) kali secara patut dan tertulis

Menurut Yahya Harahap, "Pemanggilan adalah perintah menghadiri sidang pada hari yang ditentukan. Sedangkan panggilan dalam arti luas meliputi tindakan hukum pemberitahuan atau aanzegging (notification), yang antara lain; pemberitahuan putusan PTA dan MA, permintaan Banding, memori, kontra memori banding dan lainlain". ${ }^{11} \mathrm{Hal}$ hal lain ini termasuk segala pemanggilan dalam konteks perdata seperti surat pemanggilan karyawan. Tujuan dari pemanggilan ini adalah untuk mengetahui tindakan apa yang hendak dilakukan oleh pekerja maupun pengusaha dan mencari kesepakatan jika terdapat sebuah permasalahan yang mengakibatkan pekerja mangkir.

Sedangkan Yang dimaksud dengan pemanggilan secara patut adalah panggilan untuk buruh dimana pemanggilan tersebut dilakukan secara tertulis ke alamat tempat tinggal pekerja tercatat berdasarkan data diri yang diberikan pekerja kepada pengusaha. Tenggang waktu pemanggilan sendiri tidak diatur dalam Undang-undang nomor Cipta Kerja, namun di dalam Undang-Undang Ketenagakerjaan diatur jangka waktu antara pemanggilan pertama maupun kedua yaitu paling sedikit 3 hari kerja.

Namun Undang-undang ketenagakerjaan sendiri tidak memberikan kejelasan kapan hubungan kerja benarbenar terjadi, apakah setelah surat kedua ditujukan dan pekerja tidak hadir atau tidak. Untuk menjawab pertanyaan

\footnotetext{
${ }^{11}$ Harahap, Yahya. (2004). Hukum Acara Perdata. Jakarta: Sinar Grafika 2004, h. 213.
} 
tersebut Juanda Pangaribuan, seorang praktisi hukum, memiliki pendapat bahwa mangkir benar-benar dapat terpenuhi setelah pekerja tidak memenuhi pemaanggilan yang dilakukan pengusaha tanpa harus menunggu beberapa hari kemudian. Hal ini disebabkan bahwa pada dasarnya penafsiran terhadap pasal tersebut harus berdarkan adanya itikad baik yang ditunjukkan maisng-masing pihak. Pekerja sendiri memiliki kewajiban untuk bekerja dan apabila pekerja tidak dapat masuk bekerja tentunya ia harus menunjukkan itikad baiknya dengan memberikan informasi kenapa ia tidak dapat bekerja. ${ }^{12}$

Jika Pekerja telah memenuhi 3 (tiga) unsur diatas maka pekerja dapat dikualifikasikan mangkir dimana oleh sebab hal tersebut pemutusan hubungan kerja dapat dilaksanakan. Meskipun sebenarnya pemutusan kerja merupkan hal yang sangat dihindari sebab di dalam Undang-undang Nomor Cipta Kerja dikatakan bahwa:

"(1) Pengusaha, pekerja/buruh, serikat pekerja serikat buruh, dan Pemerintah harus mengupayakan agar tidak terjadi pemutusan hubungan kerja."

Namun ada kalanya hubungan kerja tetap terjadi, oleh sebab itu dalam Undang-Undang Cipta Kerja memberikan aturan alasan putusnya hubungan kerja salah satunya dikarenakan pekerja yang mangkir.

Dalam Undang-Undang Cipta Kerja sendiri terdapat beberapa perbedaan terkait karyawan yang dianggap mangkir dibandingkan dengan yang tetulis dalam Undang-Undang Ketenagakerjaan dimana karyawan mangkir tanpa keterangan tertulis yang tidak disertai dengan bukti yang sah dianggap mengundurkan diri. Klausal tersebut ada di Pasal 168 Undang-Undang Nomor 13 Tahun 2003 yang berbunyi:

"(1) Pekerja/buruh yang mangkir selama 5 (lima) hari kerja atau lebih berturut-turut tanpa keterangan secara ter tulis yang dilengkapi dengan bukti yang sah dan telah dipanggil oleh pengusaha 2 (dua) kali secara patut dan tertulis dapat diputus hubungan kerjanya karena dikualifikasikan mengundurkan diri.

(2) Keterangan tertulis dengan bukti yang sah sebagaimana dimaksud dalam ayat (1) harus diserahkan paling lambat pada hari pertama pekerja/buruh masuk bekerja.

(3) Pemutusan hubungan kerja sebagaimana dimaksud dalam ayat (1) pekerja/buruh yang bersangkutan berhak menerima uang penggantian hak sesuai ketentuan Pasal 156 ayat (4) dan diberikan uang pisah yang besarnya dan pelaksanaannya diatur dalam perjanjian kerja, peraturan perusahaan, atau perjanjian kerja bersama."

Dimana keadaan mangkir dianggap merupakan tindakan pengunduran diri. Sedangkan dalam Undang-Undang Cipta Kerja diberikan pilihan bahwa pengusaha bisa saja melakukan pemutusan hubungan kerja tidak serta merta dianggap mengundurkan diri. Perbedaan tersebut tentunya berimplikasi terhadap hak dan kewajiban pengusaha maupun karyawan setelah hubungan kerja berakhir. Untuk lebih jelasnya akan diuraikan di pembahasan selanjutnya.

\section{Hak Pengusaha Saat Pekerja Dengan Perjanjian Kerja Waktu Tertentu Mengakhiri Perjanjian}

Sebelum kita mendalami lebih jauh hal-hal yang berkaitan dengan hak Pengusaha saat pekerja dengan Perjanjian Kerja Waktu Tertentu mengakhiri perjanjian maka untuk lebih jelaskan penulis akan menjabarkan apa yang dimaksud dengan Perjanjian Kerja Waktu Tertentu. Berdasarkan Undang-Undang Cipta Kerja yang dimaksud dengan Perjanjian Kerja Waktu Tertentu adalah Perjanjian Kerja antara Pekerja/ Buruh dengan Pengusaha untuk mengadakan Hubungan Kerja dalam waktu tertentu atau untuk pekerjaan tertentu. Dalam Pasal 59 Undang-Undang Cipta Kerja diatur lebih lanjut mengenai Perjanjian Kerja Waktu Tertentu yaitu:

“(1) Perjanjian kerja untuk waktu tertentu hanya dapat dibuat untuk pekerjaan tertentu yang menurut jenis dan sifat atau kegiatan pekerjaannya akan selesai dalam waktu tertentu, yaitu sebagai berikut: a. pekerjaan yang sekali selesai atau yang sementara sifatnya; $b$. pekerjaaan yang diperkirakan penyelesaiannya dalam waktu yang tidak terlalu lama; c. pekerjaan yang bersifat musiman; $d$. pekerjaan yang berhubungan dengan produk baru, kegiatan baru, atau produk tambahan yang masih dalam percobaan atau penjajakan; atau e. pekerjaan yang jenis dan sifat atau kegiatannya bersifat tidak tetap.

(2) Perjanjian kerja untuk waktu tertentu tidak dapat diadakan untuk pekerjaan yang bersifat tetap.

(3) Perjanjian kerja untuk waktu tertentu yang tidak memenuhi ketentuan sebagaimana dimaksud pada ayat (1) dan ayat (21 demi hukum menjadi perjanjian kerja waktu tidak tertentu."

12 https://www.hukumonline.com/klinik/detail/ulasan/lt5a038aec4a970/kapan-phk-karena-mangkir-dapat-dilaksanakan, diunduh pada tanggal 18 Maret 2021. 
Hal ini kemudian dijelaskan secara lebih terperinci di Peraturan Pemerintah Republik Indonesia Nomor 35 Tahun 2021 Tentang Perjanjian Kerja Waktu Tertentu, Alih Daya, Waktu Kerja Dan Waktu Istirahat, Dan Pemutusan Hubungan Kerja khususnya di Pasal 5 yang berbunyi :
"PKWT berdasarkan jangka waktu sebagaimana dimaksud dalam Pasal 4 ayat (1) huruf a dibuat untuk pekerjaan tertentu yaitu:
a. pekerjaan yang diperkirakan penyelesaiannya dalam waktu yang tidak terlalu lama;
b. pekerjaan yang bersifat musiman; atau
c. pekerjaan yang berhubungan dengan produk baru, kegiatan baru, atau produk tambahan yang masih dalam percobaan atau penjajakan."

Salah satu kriterianya menyatakan bahwa pekerjaan tersebut dapat diperkirakan penyelesaiannya dalam waktu yang tidak lama. Dalam hal ini maka ada jangka waktu dari dimulainya sampai diakhirnya perjanjian Kerja Waktu Tidak Tertentu. Dengan terpenuhinya jangka waktu yang ditetapkan maka Perjanjian Kerja Waktu Tertentu ikut berakhir. Namun dalam kenyataannya, seringkali ditemui karyawan yang terikat Perjanjian Kerja Waktu Tertentu memutuskan hubungan kerja sebelum masa perjanjian berakhir. Oleh sebab itu dibutuhkan aturan yang dapat melindungi pengusaha dikarenakan dengan tidak terpenuhinya jangka waktu kontrak perusahaan tentu mengalami kerugian dimana perusahaan harus kembali mencari kandidat, melaksanakan pelatihan kepada karyawan baru dan halhal lainnya yang dapat mengganggu operasional perusahaan. Untuk mengurangi kemungkinan tersebut maka Peraturan Pemerintah Republik Indonesia Nomor 35 Tahun 2021 Tentang Perjanjian Kerja Waktu Tertentu, Alih Daya, Waktu Kerja Dan Waktu Istirahat, Dan Pemutusan Hubungan Kerja mengatur syarat pekerja dapat mengakhiri perjanjian kerja dengan dasar pengunduran diri yang diatur dalam pasal 36 bagian I yang berbunyi Pekerja/Buruh mengundurkan diri atas kemauan sendiri dan harus memenuhi syarat:

\section{"1. mengajukan permohonan pengunduran diri secara tertulis selambat-lambatnya 30 (tiga puluh) hari sebelum tanggal mulai pengunduran diri; \\ 2. tidak terikat dalam ikatan dinas; dan \\ 3. tetap melaksanakan kewajibannya sampai tanggal mulai pengunduran diri; ”,}

Hal-hal tersebut merupakan syarat pekerja dapat mengundurkan diri dari perusahaan meskipun berada dalam Perjanjian Kerja Waktu Tertentu dengan mengurangi resiko kerugian bagi perusahaan. Namun pada kenyataannya, pengusaha tidak berada di posisi yang diuntungkan sebab meskipun yang mengakhiri perjanjian kerja waktu tertentu adalah pihak karyawan, namun yang diberatkan dalam pemenuhan kewajiban adalah pihak perusahaan dikarenakan pihak perusahaan harus membayar uang kompensasi atas putusnya perjanjian kerja waktu tertentu tersebut. Hal ini dicerminkan dalam pasal Pasal 17:

"Dalam hal salah satu pihak mengakhiri Hubungan Kerja sebelum berakhirnya jangka waktu yang ditetapkan dalam PKWT, Pengusaha wajib memberikan uang kompensasi sebagaimana dimaksud dalam Pasal 15 ayat (1) yang besarannya dihitung berdasarkan jangka waktu PKWT yang telah dilaksanakan oleh Pekerja/Buruh."

Dalam pasal tersebut disebutkan "dalam hal salah satu pihak" dimana ini dapat merupakan pihak pekerja maupun pengusaha sehingga dapat diambil kesimpulan bahwa meskipun perjanjian kerja waktu tertentu diakhiri oleh pekerja, namun pengusaha harus tetap dibebankan dengan uang kompensasi sedangkan sanksi kepada pekerja yang mengakhiri hubungan kerja tanpa memenuhi aturan tidak dijelaskan di dalam undang-undang.

Namun meskipun begitu, pengusaha masih bisa memiliki perlindungan dengan membuat aturan yang tertuang dalam perjanjian yang dapat mengatur sanksi kepada pekerja yang mengakhiri hubungan kerja tanpa memenuhi syarat yang tertuang dalam Pasal 36. Aturan tersebut dapat dituangkan ke dalam Perjanjian Kerja Waktu Tertentu dan ke dalam peraturan perusahaan.

Peraturan Perusahaan sendiri adalah peraturan yang dibuat secara tertulis oleh pengusaha yang memuat ketentuan tentang syarat kerja serta tata tertib perusahaan. Peraturan Perusahaan dibuat untuk menjadi pegangan bagi Perusahaan maupun karyawan yang berisikan tentang hak-hak dan kewajiban masing-masing pihak dengan tujuan memelihara hubungan kerja yang baik dan harmonis antara pengusaha dan karyawan, dalam usaha bersama meningkatkan kesejahteraan karyawan dan kelangsungan usaha perusahaan. ${ }^{13}$

Setiap perusahaan yang bergerak dalam bidang apapun pasti membutuhkan sebuah aturan yang dipatuhi oleh seluruh karyawan agar perusahaan dapat berjalan dengan baik karena pengusaha dan pekerja melaksanakan

\footnotetext{
${ }^{13}$ Asyhadie Zaeni, Hukum Kerja. Jakarta. Raja Grafindo Persada, 2008, hlm. 19.
} 
kewajibannya masing-masing oleh sebab itu Peraturan Perusahaan diwajibkan di sebuah perusahaan. Peraturan perusahaan diwajibkan bagi pengusaha yang memiliki pekerja paling sedikit 10 (sepuluh) orang. Peraturan Perusahaan dianggap berlaku jika sudah mendapat pengesahan dari Menteri TenagaKerja dan Transmigrasi atau Pejabat yang ditunjuk seperti Dinas Tenaga Kerja Provinsi maupun Kota. Peraturan Perusahaan sendiri berlaku untuk jangka waktu 2 (dua) tahun serta wajib diperpanjang atau diperbaharui setiap kali masa berlaku telah selesai.

Selain melalui peraturan perusahaan, ada cara lainnya untuk melindungi pekerja yaitu melalui perjanjian kerja yang dapat memuat ketentuan yang dapat diatur untuk melindungi pengusaha. Perjanjian kerja adalah suatu perjanjian dimana pihak yang satu sebagai buruh atau pekerja mengikatkan dirinya untuk dibawah perintahnya bekerja pada pihak lainnya sebagai majikan dengan mendapatkan upah selama waktu tertentu. ${ }^{14}$

Perjanjian Kerja juga memiliki arti lainnya, Imam Soepomo, menyatakan bahwa: "Perjanjian kerja adalah suatu perjanjian dimana pihak pertama, buruh, mengikatkan diri untuk bekerja dengan menerima upah pada pihak lainnya, majikan, yang mengikatkan diri untuk mengerjakan buruh itu dengan membayar upah. Perjanjian antara seorang "buruh" dengan seorang "majikan" perjanjian mana yang ditandai oleh cirri-ciri, adanya suatu upah atau gaji tertentu yang diperjanjikan dan adanya hubungan diperatas (dierstverhanding) yaitu suatu hubungan berdasarkan mana pihak yang satu (majikan) berhak memberikan perintah-perintah yang harus ditaati oleh pihak yang lain (buruh)." 15

Sedangkan R. Subekti memberikan arti dari perjanjian kerja. Beliau mengatakan bahwa: ${ }^{16}$

"Perjanjian kerja itu adalah suatu perjanjian antara orang perorang pada satu pihak dengan pihak lain sebagai majikan untuk melaksanakan suatu pekerjaan dengan mendapatkan upah”.

Perjanjian memiliki sifat yang mengikat kedua belah pihak seperti di dalam Pasal 1338 ayat (1) KUH Perdata menyatakan bahwa:

“semua perjanjian yang dimuat secara sah mengikat para pihak sebagai Undang-undang”.

Maka pengusaha dapat membuat perjanjian yang mengikat tanpa menyampingkan aturan dalam peraturan perundang-undangan. Contoh yang sering ditemui adalah dengan menjadikan ijazah sebagai benda jaminan. Ketentuannya sendiri yaitu bahwa pekerja harus menyerahkan ijazahnya kepada pihak perusahaan sebagai jaminan bahwa pekerja akan benar-benar menyelesaikan perjanjian kerja waktu tertentu sesuai dengan masa berlakunya. Dengan adnaya penahan ijazah maka pengusaha akan lebih mudah untuk menerapkan syarat pengunduran diri seperti yang diatur dalam Peraturan Pemerintah Republik Indonesia Nomor 35 Tahun 2021 Tentang Perjanjian Kerja Waktu Tertentu, Alih Daya, Waktu Kerja Dan Waktu Istirahat, Dan Pemutusan Hubungan Kerja mengatur syarat pekerja dapat mengakhiri perjanjian kerja dengan dasar pengunduran diri yang diatur dalam pasal 36 bagian I Karena pekerja masih memiliki hal penting yang harus dikembalikan oleh perusahaan.

Dengan adanya Undang-undang Cipta Kerja dapat disimpulkan bahwa hak pengusaha untuk pekerja yang terikat dalam perjanjian kerja waktu tertentu sangat terbatas. Hal ini sangat berbeda dengan yang ada di dalam Undang-undang No 13 Tahun 2003 yang lebih menjamin hak pengusaha sebab di dalam pasal 62 disebutkan

"Apabila salah satu pihak mengakhiri hubungan kerja sebelum berakhirnya jangka waktu yang ditetapkan dalam perjanjian kerja waktu tertentu, atau berakhirnya hubungan kerja bukan karena ketentuan sebagaimana dimaksud dalam Pasal 61 ayat (1), pihak yang mengakhiri hubungan kerja diwajibkan membayar ganti rugi sebesar upah pekerja/buruh sampai batas waktu berakhirnya waktu perjanjian kerja."

Jadi jika perjanjian kerja berakhir maka pekerja memiliki kewajiban untuk mengganti sisa waktu berakhirnya perjanjian kerja sehingga hal ini tentu akan berdampak dengan komitmen pekerja yang kuat untuk tetap melaksanakan kewajibannya sebagai pekerja sampai masa waktu perjanjian kerja waktu tertentu berakhir. Apalagi mangkir dalam Undang-Undang Nomor 13 Tahun 2003.dianggap sebagai pengunduran diri bukan Pemutusan Hubungan Kerja maka karyawan tidak berhak memperoleh uang penggantian hak, uang pesangin maupun uang pisah. Satu-satunya cara agar pengusaha bisa mendapatkan haknya dan juga perlindungannya yaitu melalui penambahan aturan-aturan yang tertulis dalam Peraturan Perusahaan maupun di dalam Perjanjian Kerja.

${ }^{14}$ Pasal 1601a Kitab Undang-Undang Hukum Perdata

${ }^{15}$ Soepomo, Imam. (1968). Hukum Perburuhan Bagian Pertama Hubungan Kerja. Jakarta: PPAKRI Bhayangkara, 1968, h.

${ }^{16}$ Subekti, R. (1997). Aneka Perjanjian. Bandung: Alumni, 1977, h. 63. 


\section{SIMPULAN}

Dari Pembahasan diatas maka dapat diketahui bahwa untuk dikategorikan mangkir maka ada beberapa hal yang harus di perhatikan yaitu karyawan tidak masuk bekerja selama 5 hari kerja atau lebih, karyawan tidak memberikan keterangan yang tertulis dengan bukti yang sah, karyawan telah dipanggil oleh pengusaha 2 (dua) kali secara patut dan tertulis Namun Undang-undang ketenagakerjaan sendiri tidak memberikan kejelasan kapan hubungan kerja benarbenar terjadi, apakah setelah surat kedua ditujukan dan pekerja tidak hadir atau tidak. Untuk menjawab pertanyaan tersebut Juanda Pangaribuan, seorang praktisi hukum, memiliki pendapat bahwa mangkir benar-benar dapat terpenuhi setelah pekerja tidak memenuhi pemanggilan yang dilakukan pengusaha tanpa harus menunggu beberapa hari kemudian. Hal ini disebabkan bahwa pada dasarnya penafsiran terhadap pasal tersebut harus berdarkan adanya itikad baik yang ditunjukkan maisng-masing pihak. Pekerja sendiri memiliki kewajiban untuk bekerja dan apabila pekerja tidak dapat masuk bekerja tentunya ia harus menunjukkan itikad baiknya dengan memberikan informasi kenapa ia tidak dapat bekerja. Jika Pekerja telah memenuhi 3 (tiga) unsur diatas maka pekerja dapat dikualifikasikan mangkir dimana oleh sebab hal tersebut pemutusan hubungan kerja dapat dilaksanakan.

Karyawan yang terikat Perjanjian Kerja Waktu Tertentu seringkali memutuskan hubungan kerja sebelum masa perjanjian berakhir. Oleh sebab itu dibutuhkan aturan yang dapat melindungi pengusaha dikarenakan dengan tidak terpenuhinya jangka waktu kontrak perusahaan tentu mengalami kerugian dimana perusahaan harus kembali mencari kandidat, melaksanakan pelatihan kepada karyawan baru dan hal-hal lainnya yang dapat mengganggu operasional perusahaan. Untuk mengurangi kemungkinan tersebut maka Peraturan Pemerintah Republik Indonesia Nomor 35 Tahun 2021 Tentang Perjanjian Kerja Waktu Tertentu, Alih Daya, Waktu Kerja dan Waktu Istirahat, Dan Pemutusan Hubungan Kerja mengatur syarat pekerja dapat mengakhiri perjanjian kerja dengan dasar pengunduran diri yang diatur dalam pasal 36 bagian I yang berbunyi Pekerja/Buruh mengundurkan diri atas kemauan sendiri dan harus memenuhi syarat yang ditentukan dalam Undang-undang.

\section{DAFTAR PUSTAKA \\ Buku}

Asyhadie Zaeni, Hukum Kerja. Jakarta. Raja Grafindo Persada, 2008.

Febri Jaya, "Perlindungan Hak-Hak Pekerja Perempuan Pasca Revisi Undang-Undang Ketenagakerjaan Dalam Omnibus Law", Jurnal Kertha Semaya, Volume 8, No. 12, 2020

Harahap, Yahya. (2004). Hukum Acara Perdata. Jakarta: Sinar Grafika 2004

Soepomo, Imam. (1968). Hukum Perburuhan Bagian Pertama Hubungan Kerja. Jakarta: PPAKRI Bhayangkara, 1968.

Subekti, R. (1997). Aneka Perjanjian. Bandung: Alumni, 1977.

Soekanto, Soerjono dan Sri Mamudji. Penelitian Hukum Normatif Suatu Tinjauan Singkat, (Jakarta, RajaGrafindo Persada, 2003).

Marzuki, Peter Mahmud. Penelitian Hukum, (Jakarta, Kencana, 2014).

Ibrahim, Johnny. Teori dan Metode Penelitian Hukum Normatif, (Malang, Bayumedia Publishing, 2003).

Mertokusumo, Sudikono. Mengenal Hukum (Suatu Pengatar), (Yogyakarta, Liberty, 1991).

Velis Alicia Pui, "Analisis Yuridis Penyelesaian Sengketa Pemutusan Hubungan Kerja Terhadap Tenaga Kerja Asing Melalui Mediasi (Studi Penelitian di Dinas Tenaga Kerja Kota Batam)", Jurnal Wajah Hukum, Volume 4 No 2, 2020.

\section{Undang-Undang}

Kitab Undang-Undang Hukum Perdata

\section{Internet}

https://www.hukumonline.com/klinik/detail/ulasan/lt5a038aec4a970/kapan-phk-karena-mangkir-dapat-dilaksanakan, diunduh pada tanggal 18 Maret 2021. 